\title{
EFFECTS OF RIPARIAN VEGETATION INTEGRITY ON FISH AND HETEROPTERA COMMUNITIES
}

\author{
VIEIRA, T. B. ${ }^{1} *$-DIAS-SILVA, $\mathrm{K}^{2}{ }^{2}-$ PACÍFICO, E. S. ${ }^{3}$ \\ 'Programa de Pós-graduação em Ecologia e Evolução, Departamento de Ecologia, Instituto de \\ Ciências Biológicas (ICB), Universidade Federal de Goiás (UFG), \\ Goiânia, GO, Brazil, CX 24.223, CEP 74690-970. \\ (phone: +55 62 9178-0540) \\ ${ }^{2}$ Programa de Pós-graduação em Ciências Ambientais, Departamento de Ecologia, Instituto de \\ Ciências Biológicas (ICB), Universidade Federal de Goiás (UFG), \\ Goiânia, GO, Brazil, CEP 74690-970. \\ (phone: +55 62 8203-2698) \\ ${ }^{3}$ Instituto de Pesquisas Ambientais da Amazônia - IPAM, \\ Rua Horizontina, 104, Centro, Canarana, MT, Brazil. CEP 78640-000. \\ (phone: +55 62 3521-1373) \\ *Corresponding author \\ e-mail: thiagobernardi007@gmail.com \\ (Received $7^{\text {th }}$ Nov 2013; accepted $14^{\text {th }}$ Aug 2014)
}

\begin{abstract}
Freshwater ecosystems are essential to human societies. However, many anthropogenic activities have been constantly modifying these ecosystems. Such modifications can be detected and measured with the use of environmental bioindicators. This work aims to identify the effect of physical integrity of streams, riparian vegetation coverage and physical and physicochemical variables on fish and Heteroptera faunas of streams, identifying which group is a better indicator of environmental disturbance. Predictor variables were sorted into three matrices: (1) physical and physicochemical parameters of the streams, (2) environmental variables and (3) structural variables of riparian vegetation. We tested the effects of physical and physicochemical descriptors on species richness and abundance through multiple linear regressions. The effects of environmental and structural variables of the riparian vegetation were tested using ridge regressions. Physical and physicochemical variables had no effect on Heteroptera and fish communities. Environmental variables showed effect only on the community of Heteroptera. Ichthyic assemblages were not influenced by any environmental variables. Selected structural variables had no relation with the Heteroptera assemblages, neither with fish community. Therefore, we conclude that, in small Amazonian streams, Heteroptera is more sensitive to human impacts than fish. This sensibility is demonstrated by the negative relation between Heteroptera fauna and the canopy opening over the river and positively related to environment integrity. These associations were not found for icthyofauna.
\end{abstract}

Keywords: fish community; aquatic insects; habitat integrity; Normalized Difference Vegetation Index (NDVI); Enhanced Vegetation Index (EVI); bioindicator

\section{Introduction}

Freshwater ecosystems are highly important to human societies, especially in respect tosupply of water to animal watering, fishing, agricultural and industrial production. Despite this recognition, various human activities have been leading to constant changes in aquatic environments (Greenwood et al., 2004; Holland-Clift et al., 2011; Richter, 2003), reducing the ecological quality of aquatic ecosystems (for example, by increasing water temperature). Consequently, ecosystem processes are also negatively affected by anthropogenic activities (e.g., water purification). Subsequently, the 
availability of social and economic usage of this resource is decreased. Therefore, a major goal of the management of water resources is to restore or maintain the ecological integrity of these ecosystems (Karr, 1993).

Rivers and streams can be described as continuous longitudinal gradients of physical and physical-chemical conditions, where the biota is directly related to this dynamic (Vannote et al., 1980). The degree of dependence on vegetation is inversely proportional to volume of water (Minshall et al., 1983). Montgomery (1999) suggests that in addition to environmental and physical variables, geomorphological processes represented by the topography, climate and geology, may also determine the quality, the availability and the distribution of habitats - and consequently, wildlife. Thus, physical and chemical monitoring of water is not sufficient to detect changes in habitat and microhabitat availability in aquatic ecosystems (e.g., De Marco et al., 2005). As a result, measuring environmental changes in physical, chemical and physicochemical parameters may not capture variations in the community structures of aquatic organisms (e.g., Callisto et al., 2005; Murray and Innes, 2009; Warren et al., 2010).

By contrast, disturbances or changes in aquatic ecosystems can be detected and measured with the assistance of environmental bioindicators (Oertli, 2008). Since biological communities are determined by local environmental conditions, they are able to reflect the ecological integrity of ecosystems (e.g., physical and chemical integrity and changes in the availability of food resources and substrates) in a more accurate way (e.g., Barbour et al., 1999). Since biomonitoring consists of the systematic use of biological responses to assess environmental changes, it can be considered as a way to assess the "health" of ecosystems (Buss, 1986).

The selection of adequate taxa to be used as bioindicators relies on a variety of factors, such as: (i) type of environment to be assessed, (ii) local community, (iii) costs of collection and identification and, especially, (iv) the community response to impacts on the environment. Since aquatic invertebrates and fish present high biodiversity and occur in almost all aquatic systems, having tolerant and susceptible species to different types of impacts (Callisto, 2001; Callisto et al., 2001; Resh et al., 1995; Rosenberg and Resh, 1993), they can be considered good bioindicators.

This study aims to identify the relationship between environmental (physical integrity of streams and riparian vegetation coverage), physical and physicochemical variables on the icthyofauna and on Heteroptera fauna of streams. We predict that Heteroptera fauna will respond to environmental variations whereas fish fauna will respond to physical and physicochemical variables.

\section{Methods}

This study was conducted in 21 streams of the headwaters of the Xingu River basin, in the municipalities of Canarana, Água Boa and Querência, state of Mato Grosso, Brazil, (Fig. 1, Table 1). These municipalities are situated in the Amazonian Deforestation Arc and have been submitted to high deforestation rates in the last decades. Samples were collected in a single step, between June and July 2011. In each stream, a stretch of $100 \mathrm{~m}$ was demarked and then divided into 20 segments of five meters. Fish were collected using the trawl method. In each segment, a trawl net was dragged once towards the longitudinal direction of the stream. Once collected, fish were

fixed in formaldehyde $10 \%$ solution. In laboratory, fish were washed to remove any excess of formaldehyde, and then identified. Identification and systematic sorting 
followed current literature (e.g. Buckup, 1993; Vari and Williams, 1987; Vari, 1991, 1989) going until species level, whenever possible.

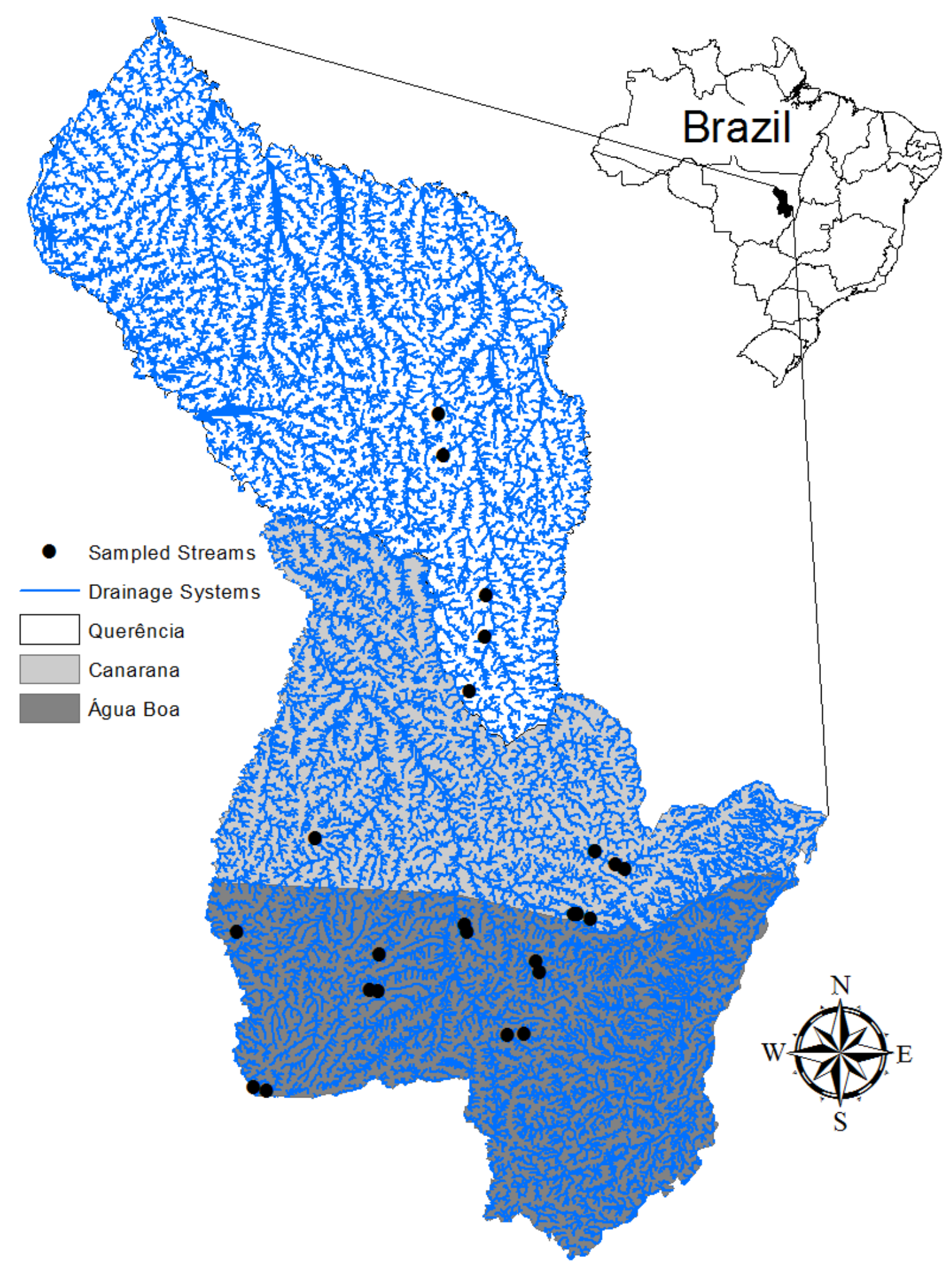

Figure 1. Location of the streams sampled (black circles) in the Xingu River basin, Central Brazil. 
Table 1. Sampled streams at the Upper Xingu Basin, Mato Grosso, Brazil.

\begin{tabular}{|c|c|c|c|c|c|}
\hline \multirow{2}{*}{ Acronym } & \multirow{2}{*}{ Municipality } & \multirow{2}{*}{ Use of Soil } & \multirow{2}{*}{ Date } & \multicolumn{2}{|c|}{ Coordinates } \\
\hline & & & & Lat & Long \\
\hline A1 & Canarana & Pasture/Cerrado & 04/jul/11 & -13.55 & -52.03 \\
\hline A3 & Canarana & Pasture/Cerrado & 09/jul/11 & -13.59 & -51.97 \\
\hline A4 & Canarana & Pasture /Cerrado & 09/jul/11 & -13.6 & -51.94 \\
\hline B1 & Canarana & Sugarcane/Cerrado & 08/jul/11 & -13.73 & -52.08 \\
\hline B2 & Canarana & Pasture & 08/jul/11 & -13.73 & -52.09 \\
\hline $\mathrm{C} 1$ & Canarana & Recovery Area & 17/jul/11 & -13.51 & -52.81 \\
\hline D1 & Água Boa & Pasture & 17/jul/11 & -13.78 & -53.03 \\
\hline E1 & Água Boa & Pasture & 13/jul/11 & -13.94 & -52.66 \\
\hline E2 & Água Boa & Pasture & 13/jul/11 & -13.94 & -52.63 \\
\hline $\mathrm{F} 2$ & Água Boa & Pasture & 14/jul/11 & -13.84 & -52.63 \\
\hline G1 & Água Boa & Pasture & 12/jul/11 & -13.77 & -52.38 \\
\hline G2 & Água Boa & Pastu & 12/jul/11 & -13.75 & -52.39 \\
\hline H1 & Água Boa & Pastu & 11/jul/11 & -13.86 & -52.19 \\
\hline $\mathrm{H} 2$ & Água Boa & Pasture & 11/jul/11 & -13.89 & -52.18 \\
\hline I1 & Água Boa & Pasture /Cerrado & 15/jul/11 & -14.21 & -52.98 \\
\hline $\mathrm{I} 2$ & Água Boa & Cerrado & 15/jul/11 & -14.22 & -52.94 \\
\hline K1 & Querência & Soy & 06/jul/11 & -12.45 & -52.45 \\
\hline K2 & Querência & For & 06/jul/11 & -12.33 & -52.47 \\
\hline L1 & & Fore & 07/jul/11 & -13.1 & -52.38 \\
\hline L2 & & Forest & 05/jul/11 & -12.84 & -52.33 \\
\hline L4 & Querência & Soy & 05/jul/11 & -12.95 & -52.34 \\
\hline
\end{tabular}

Meanwhile, the semi-aquatic Heteroptera (Gerromorpha) were collected with the assistance of a strainer. In each of the 20 segments of five meters, we sieved the water three times (left, right and center segments), in downstream-upstream direction(Cabette et al., 2010). Individuals collected in each segment were separated and identified by segment and stream. Collected material was sorted and stored in commercial ethanol (concentration of 85\%) and identified until genus level with the aid of the taxonomic keys of Nieser and Melo (1997) and Pereira and Melo (2007). All specimens of fish and Heteroptera are deposited in the Zoological Collection of the Federal University of Goiás (ZUFG).

Ecological integrity of streams was measured by species richness and abundance of individuals. Species richness of fish was estimated by Jackknife method (Heltshe and Forrester, 1983), using the software EstimateS version 8.0 (Colwell, 2005). The segments of each stream were classified as pseudo-samples and 1000 iterations were performed. For Heteroptera, we considered the observed richness of genera. Predictor variables were divided into three matrices: (i) physical and physicochemical parameters of the streams, (ii) environmental variables and (iii) structural variables of riparian vegetation.

Physicochemical and physical variables of the streams used in this study were: width, depth, slope, water temperature, dissolved oxygen, conductivity and $\mathrm{pH}$. Width was measured every $20 \mathrm{~m}$. Depth was also measured three times per stream, distant 20 meters from each other. Slope was measured with the assistance of two rulers and a transparent tube (10m length) containing water inside. We estimated slope by submerging the whole tube and positioning the tips above the water layer, and 
calculating the difference between both measures of the air bubble height in each side of the tube. This procedure was repeated five times in each stream (i.e., a measurement was taken every $10 \mathrm{~m}$ ). We used a multi-parameter probe YSI Professional Plus to measure water temperature, dissolved oxygen, conductivity and $\mathrm{pH}$.

The environmental variables we have used were: (i) Index of Habitat Integrity (IHI; Nessimian et al., 2008), (ii) incident luminosity and (iii) canopy openness over the stream. They were extracted from 30 pictures in each stream (15 on each side of the stream) that were obtained parallel to the ground, at a height of $30 \mathrm{~cm}$ from the water blade immediately above from the stream margin. Structural variables were determined by two riparian vegetation indices: (i) Normalized Difference Vegetation Index (NDVI) and (ii) Enhanced Vegetation Index (EVI).

Vegetation indices (VI) employed here were obtained from Landsat TM images (May 2010, orbits 222 and 223, points 69 and 70) that present a spatial resolution of 30 x $30 \mathrm{~m}$ and have seven spectral bands. Chosen images minimized the amount of clouds that could generate noise in the data. We made a color composite based in the bands TM5, TM3 and TM4 of the images. We used the cubic convolution resampling of pixels of each scene, based on the georeferenced mosaic Geocover NASA. Then, we calculated two VI of the images: (i) Normalized Difference Vegetation Index (NDVI), (Rouse et al., 1974) and (ii) Enhanced Vegetation Index (EVI) (Huete et al., 1997). Each VI measure was taken the creation of nine buffers $(30,90,150,210,270,330$, 390,450 e 510 meters) around each sampled point and the obtention of the average (representing the density of vegetation coverage) and standard deviation (representing the heterogeneity of vegetation cover) of both VI.

First, we tested the effect of physical and physicochemical descriptors ( $\mathrm{pH}$, water temperature, dissolved oxygen, conductivity, slope, width and depth) on the descriptors of the assemblages (i.e., species richness and abundance) through multiple linear regressions. Prior to these analyses, we used Pearson correlations to exclude correlated descriptors (i.e., descriptors that presented a correlation equal to or greater than 0.75 were removed from the analyses).

The effect of environmental variables (canopy openness and integrity of habitat) on the descriptors of the assemblages (richness and abundance) was tested using ridge regressions. This approach was adopted due to collinearity found between the predictor variables $(\mathrm{HIH}$, mean canopy openness $(\mathrm{M})$, standard deviation of canopy openness (SD) and median canopy openness (MD).

We also used ridge regressions to teste the effect of structural variables of the riparian vegetation (complexity and heterogeneity of riparian vegetation) on the descriptors of the assemblages (species richness and abundance). Regressions were performed between complexity of riparian vegetation, NDVI and EVI, and the descriptors of biotic assemblages (species richness and abundance). Additionally, we tested the effect of heterogeneity of riparian vegetation, NDVI and EVI, and the descriptors of biotic assemblages, also using ridge regression. Adopted lambda for ridge regressions was of 0.01 .

\section{Results}

We collected and identified 4,961 individuals of Heteroptera that were distributed into 4 families and 15 genera (Table 2). The most abundant genera were Rhagovelia (2,063), Stridulivelia (1,212), Neogerris (524), Brachymetra (443) and Cylindrostethus 
(419), representing, respectively, $42 \%, 24 \%, 11 \%, 9 \%$ and $8 \%$ of the total number of collected individuals. We obtained 1,333 fishes belonging to 37 species, divided between the orders Characiformes, Siluriformes, Gymnotiformes and Perciformes, $75 \%$, $18 \%, 5 \%, 2 \%$ respectively, of the total number of collected individuals (Table 3).

Table 2. Genera of Heteroptera (Gerromorpha) collected in the Upper Xingu, Mato Grosso, Brazil. Genera are sorted by Family. The values represent the abundance of individuals of each genus.

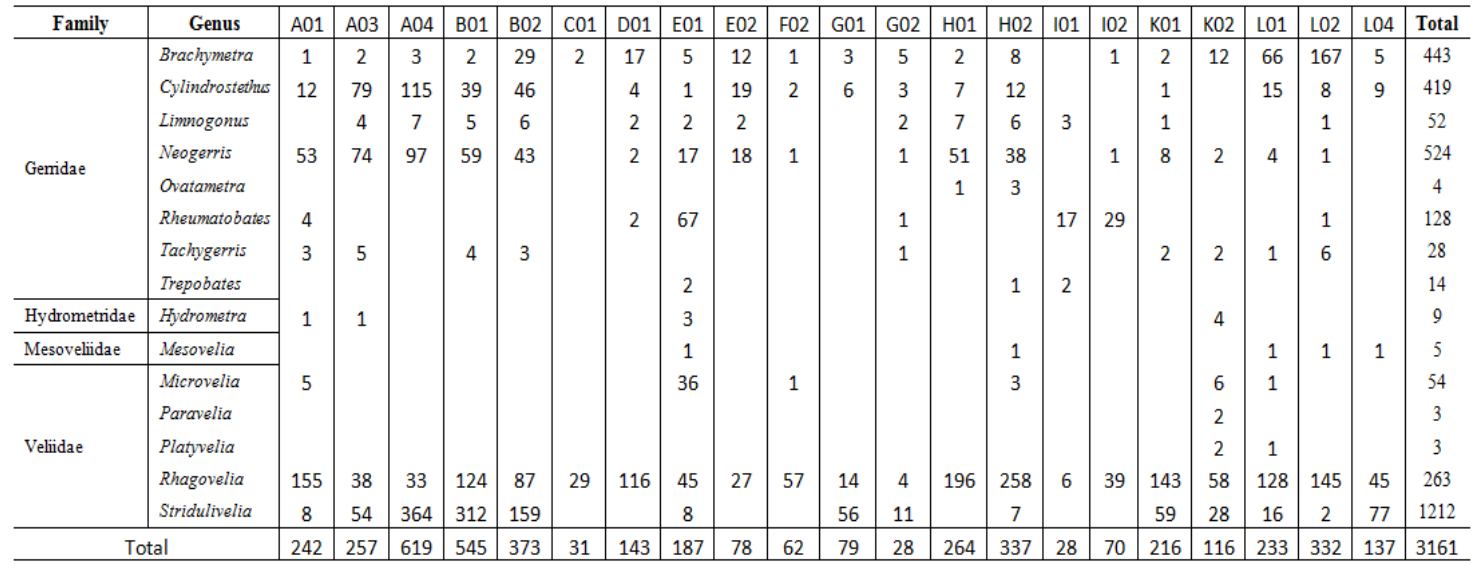

Table 3. Fish species collected in the Upper Xingu, Mato Grossom Brazil. Species are sorted by Order and by Family. The values represent the abundance of individuals of each species

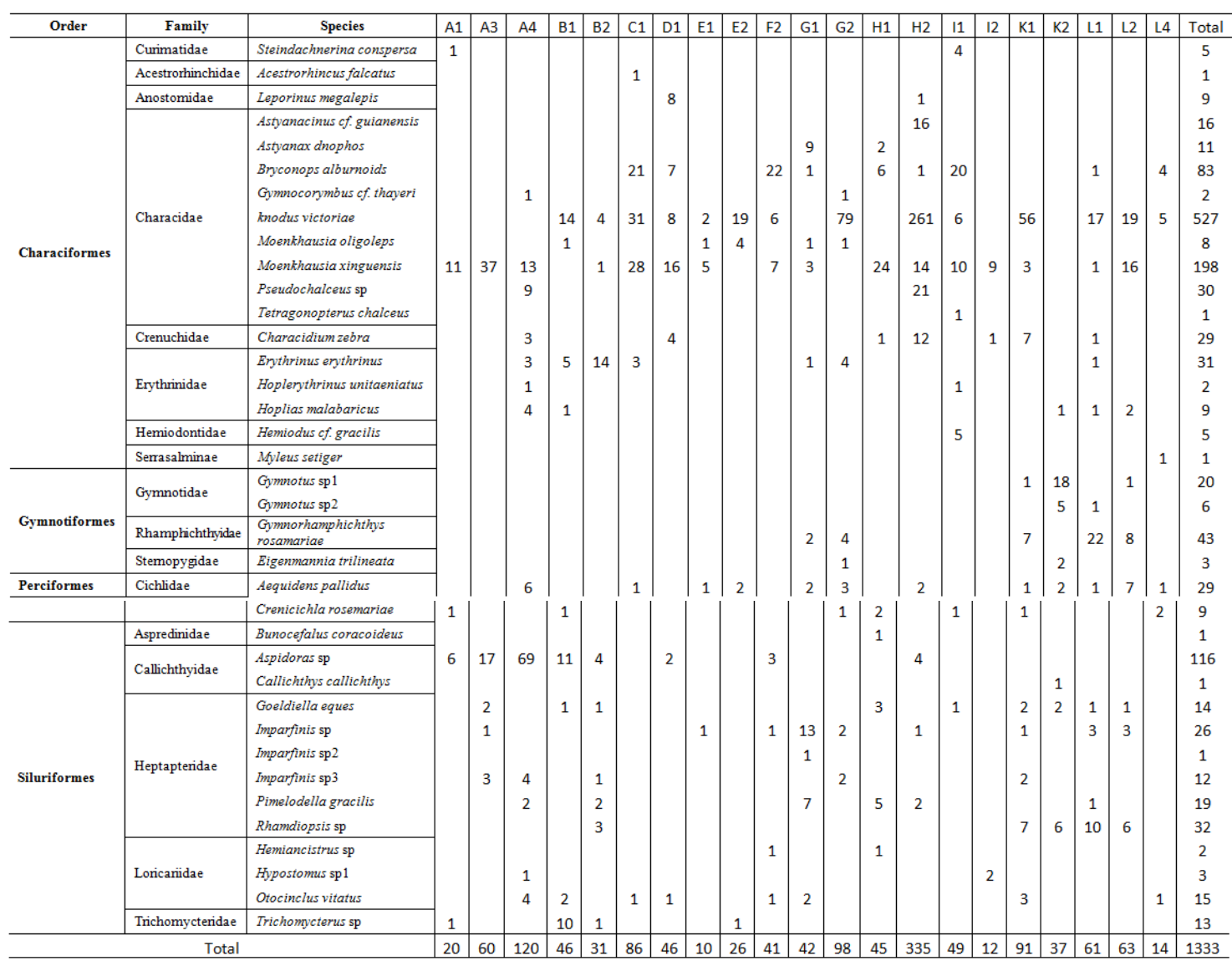


The most dominant species was Knodus victoriae that counted with 537 individuals collected, followed by Moenkhausia xinguensis and Aspidoras sp., with 243 and 116 specimens respectively.

Due to high correlation with other variables (equal or higher than 0.75 ) used in the regression models (Table 4), parameters of dissolved oxygen percentage, electric conductivity, slope and depth were not considered in regressions performed with physical and physicochemical variables. Physical and physicochemical variables had no effect on the communities of Heteroptera and fish (Table 5).

Table 4. Pearson correlation between the physical and physicochemical data collected in 21 streams in the basin of the Upper Xingu, Mato Grosso, Brazil. Acronyms: $p H$ -

hydrogenionic potential; Water Temp. - water temperature; DO - percentage of dissolved oxygen; DOm - dissolved oxygen in milligrams per liter of water; SPC - specific conductivity; $C$ - conductivity; Slope A - average slope of the stream; Slope SD - standard deviation of the slope of the stream; Width A - average width of the stream; Width SD standard deviation of the stream channel width; Depth A - average depth of the stream, and; Depth SD - standard deviation of the stream depth.

\begin{tabular}{|c|c|c|c|c|c|c|c|c|c|c|c|c|}
\hline & $\stackrel{T}{2}$ & 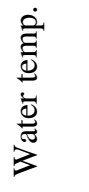 & ஜ & §్ & $\frac{u}{n}$ & U & $\begin{array}{l}\varangle \\
0 \\
\stackrel{0}{0} \\
\frac{0}{n}\end{array}$ & 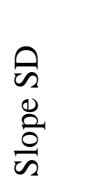 & $\begin{array}{l}\varangle \\
\text { E } \\
\vdots \\
\vdots\end{array}$ & $\begin{array}{l}\text { 命 } \\
\text { 声 } \\
\text { 章 }\end{array}$ & 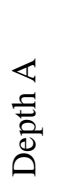 & 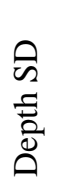 \\
\hline $\mathrm{pH}$ & 1.00 & & & & & & & & & & & \\
\hline $\begin{array}{l}\text { Water } \\
\text { temp. }\end{array}$ & -0.66 & 1.00 & & & & & & & & & & \\
\hline DO & 0.19 & -0.28 & 1.00 & & & & & & & & & \\
\hline Dom & 0.34 & -0.49 & 0.97 & 1.00 & & & & & & & & \\
\hline SPC & 0.51 & -0.24 & -0.45 & -0.34 & 1.00 & & & & & & & \\
\hline C & 0.49 & -0.20 & -0.47 & -0.37 & 1.00 & 1.00 & & & & & & \\
\hline Slope A & 0.10 & -0.01 & 0.28 & 0.26 & -0.49 & -0.49 & 1.00 & & & & & \\
\hline Slope SD & 0.22 & -0.23 & 0.24 & 0.28 & -0.25 & -0.27 & 0.83 & 1.00 & & & & \\
\hline Width A & 0.42 & -0.31 & 0.14 & 0.21 & 0.47 & 0.46 & -0.01 & 0.28 & 1.00 & & & \\
\hline Width SD & 0.13 & -0.24 & 0.08 & 0.13 & 0.31 & 0.30 & 0.01 & 0.28 & 0.62 & 1.00 & & \\
\hline Depth A & -0.19 & 0.19 & 0.09 & 0.04 & -0.08 & -0.07 & 0.10 & 0.16 & 0.32 & 0.34 & 1.00 & \\
\hline Depth SD & -0.09 & 0.07 & 0.25 & 0.22 & -0.04 & -0.03 & 0.05 & 0.21 & 0.39 & 0.47 & 0.92 & 1.00 \\
\hline
\end{tabular}

Table 5. Results of multiple regressions between the physical and physicochemical variables of the streams and the descriptors of the assemblages.

\begin{tabular}{|c|c|c|c|c|c|c|c|c|}
\hline & \multicolumn{4}{|c|}{ Fish } & \multicolumn{4}{|c|}{ Heteroptera } \\
\hline & \multicolumn{2}{|c|}{ Abundance } & \multicolumn{2}{|c|}{ Estimated Richness } & \multicolumn{2}{|c|}{ Abundance } & \multicolumn{2}{|c|}{ Observed Richness } \\
\hline & $\mathrm{B}$ & $\mathrm{p}$ & $\mathrm{B}$ & $\mathrm{p}$ & $\mathrm{B}$ & $\mathrm{p}$ & $\mathrm{B}$ & $\mathrm{p}$ \\
\hline $\mathrm{pH}$ & -0.14 & 0.81 & 0.48 & 0.37 & 1.03 & 0.03 & 0.74 & 0.09 \\
\hline Water temperature & 0.42 & 0.31 & 0.52 & 0.19 & -0.03 & 0.91 & -0.47 & 0.13 \\
\hline Dissolved Oxygen & 0.43 & 0.35 & 0.03 & 0.95 & -0.4 & 0.25 & -0.82 & 0.02 \\
\hline Electrical Conductivity & 0.15 & 0.82 & -0.66 & 0.29 & -1.28 & 0.02 & -1.31 & 0.01 \\
\hline Slope & 0.11 & 0.77 & -0.32 & 0.39 & -0.62 & 0.05 & -0.51 & 0.08 \\
\hline Width & 0.18 & 0.66 & -0.2 & 0.6 & 0.05 & 0.88 & 0.35 & 0.25 \\
\hline Depth & 0.04 & 0.90 & 0.05 & 0.86 & -0.12 & 0.61 & -0.05 & 0.83 \\
\hline $\mathrm{r}^{2}$ & \multicolumn{2}{|c|}{0.21} & \multicolumn{2}{|c|}{0.31} & \multicolumn{2}{|c|}{0.55} & \multicolumn{2}{|c|}{0.59} \\
\hline $\mathbf{P}$ & \multicolumn{2}{|c|}{0.90} & \multicolumn{2}{|c|}{0.70} & \multicolumn{2}{|c|}{0.17} & \multicolumn{2}{|c|}{0.11} \\
\hline
\end{tabular}


Environmental variables had effect only on the community of Heteroptera (Table 6). There was a positive relationship with abundance for HIH $\left(\mathrm{r}^{2}=0.21 ; \mathrm{p}=0.04\right)$, modified $\mathrm{HIH}\left(\mathrm{r}^{2}=0.22 ; \mathrm{p}=0.03\right)$ and canopy openness $\left(\mathrm{r}^{2}=0.21 ; \mathrm{p}=0.03\right)$. HIH $\left(\mathrm{r}^{2}=0.22 ; \mathrm{p}=0.03\right)$ and canopy openness $\left(r^{2}=0.21 ; p=0.03\right)$ also were positively related to genera richness of Heteroptera. Ichthyic assemblages were not affected by environmental variables.

Structural variables selected for analysis - riparian vegetation density (average NDVI and average EVI) and heterogeneity (standard deviation of NDVI and EVI) - did not correlate with Heteroptera (Table 7) or fish (Table 8) communities.

Table 6. Regressions results between environmental variables and the descriptors of the assemblages; Mean - M, Standard Deviation - SD, Median MD.

\begin{tabular}{|c|c|c|c|c|c|c|c|c|}
\hline \multirow[b]{4}{*}{$\mathrm{HIH}$} & \multicolumn{4}{|c|}{ Fish } & \multicolumn{4}{|c|}{ Heteroptera } \\
\hline & \multicolumn{2}{|c|}{ Abundance } & \multicolumn{2}{|c|}{ Richness } & \multicolumn{2}{|c|}{ Abundance } & \multicolumn{2}{|c|}{ Richness } \\
\hline & $\mathrm{B}$ & $\mathrm{P}$ & $\mathrm{B}$ & $\mathrm{P}$ & $\mathrm{B}$ & $\mathrm{p}$ & $\mathrm{B}$ & $\mathrm{P}$ \\
\hline & 0.181 & 0.700 & -0.077 & 0.880 & 0.21 & 0.04 & 0.22 & 0.03 \\
\hline Canopy openness (M) & -0.189 & 0.734 & 0.088 & 0.884 & -0.21 & 0.03 & -0.35 & 0.01 \\
\hline Canopy openness (SD) & 0.257 & 0.431 & 0.051 & 0.884 & -0.11 & 0.14 & -0.11 & 0.14 \\
\hline Canopy openness (MD) & -0.084 & 0.876 & -0.176 & 0.762 & -0.24 & 0.03 & -0.36 & 0.00 \\
\hline $\mathbf{r}^{2}$ & \multicolumn{2}{|c|}{0.088} & \multicolumn{2}{|c|}{0.437} & \multicolumn{2}{|c|}{0.426} & \multicolumn{2}{|c|}{0.367} \\
\hline $\mathbf{P}$ & \multicolumn{2}{|c|}{0.649} & \multicolumn{2}{|c|}{0.980} & \multicolumn{2}{|c|}{0.047} & \multicolumn{2}{|c|}{0.029} \\
\hline
\end{tabular}

Table 7. Regressions results between density and vegetation complexity of Heteroptera assemblages; NDVI - Normalized Difference Vegetation Index; EVI - Enhanced Vegetation Index.

\begin{tabular}{|c|c|c|c|c|c|c|c|c|c|c|c|c|c|c|c|c|}
\hline & \multicolumn{8}{|c|}{ Density } & \multicolumn{8}{|c|}{ Complexity } \\
\hline & \multicolumn{4}{|c|}{ NDVI } & \multicolumn{4}{|c|}{ EVI } & \multicolumn{4}{|c|}{ NDVI } & \multicolumn{4}{|c|}{ EVI } \\
\hline & \multicolumn{2}{|c|}{ Abundance } & \multicolumn{2}{|c|}{ Richness } & \multicolumn{2}{|c|}{ Abundance } & \multicolumn{2}{|c|}{ Richness } & \multicolumn{2}{|c|}{ Abundance } & \multicolumn{2}{|c|}{\begin{tabular}{|l} 
Richness \\
\end{tabular}} & \multicolumn{2}{|c|}{ Abundance } & \multicolumn{2}{|c|}{ Richness } \\
\hline & $\mathrm{B}$ & $P$ & $\mathrm{~B}$ & $P$ & \begin{tabular}{l|l}
$\mathrm{B}$ & \\
\end{tabular} & $\mathrm{P}$ & \begin{tabular}{l|l}
$\mathrm{B}$ & \\
\end{tabular} & $\mathrm{P}$ & \begin{tabular}{l|l}
$\mathrm{B}$ & \\
\end{tabular} & $\mathrm{P}$ & \begin{tabular}{l|l}
$\mathrm{B}$ & \\
\end{tabular} & $\mathrm{p}$ & $\mathrm{B}$ & $\mathrm{p}$ & \begin{tabular}{l|l}
$\mathrm{B}$ \\
\end{tabular} & $\mathrm{P}$ \\
\hline Point & 0.222 & 0.549 & 0.213 & 0.457 & 0.021 & 0.964 & 0.245 & 0.565 & & & & & & & & \\
\hline $90 \mathrm{~m}$ & -0.179 & 0.749 & 0.363 & 0.405 & 0.100 & 0.874 & -0.134 & 0.811 & -0.215 & 0.603 & -0.648 & 0.109 & 0.073 & 0.894 & -0.255 & 0.634 \\
\hline $150 \mathrm{~m}$ & 0.208 & 0.741 & 0.002 & 0.996 & 0.094 & 0.885 & 0.018 & 0.973 & -0.300 & 0.586 & 0.263 & 0.612 & -0.031 & 0.962 & 0.191 & 0.770 \\
\hline $210 \mathrm{~m}$ & 0.103 & 0.873 & -0.113 & 0.821 & 0.111 & 0.872 & -0.078 & 0.897 & 0.102 & 0.867 & 0.242 & 0.677 & -0.113 & 0.874 & 0.026 & 0.969 \\
\hline $270 \mathrm{~m}$ & 0.020 & 0.976 & -0.033 & 0.947 & 0.286 & 0.680 & -0.069 & 0.908 & 0.228 & 0.722 & 0.062 & 0.916 & 0.134 & 0.801 & -0.011 & 0.982 \\
\hline $330 \mathrm{~m}$ & 0.056 & 0.934 & 0.051 & 0.921 & 0.163 & 0.813 & 0.069 & 0.908 & 0.056 & 0.932 & -0.132 & 0.834 & 0.003 & 0.996 & 0.053 & 0.938 \\
\hline $390 \mathrm{~m}$ & 0.107 & 0.874 & 0.082 & 0.874 & -0.061 & 0.927 & 0.242 & 0.682 & -0.059 & 0.930 & -0.112 & 0.861 & -0.002 & 0.997 & -0.049 & 0.943 \\
\hline $450 \mathrm{~m}$ & 0.060 & 0.925 & 0.115 & 0.818 & -0.208 & 0.736 & 0.390 & 0.475 & -0.048 & 0.940 & 0.000 & 0.999 & 0.113 & 0.870 & -0.254 & 0.705 \\
\hline $\mathbf{r}^{2}$ & \multicolumn{2}{|c|}{0.230} & \multicolumn{2}{|c|}{0.542} & \multicolumn{2}{|c|}{0.286} & \multicolumn{2}{|c|}{0.453} & \multirow{2}{*}{\multicolumn{2}{|c|}{0.122}} & & & \multicolumn{2}{|c|}{0.028} & \multicolumn{2}{|c|}{0.084} \\
\hline $\mathbf{P}$ & \multicolumn{2}{|c|}{0.874} & \multicolumn{2}{|c|}{0.146} & \multicolumn{2}{|c|}{0.760} & \multicolumn{2}{|c|}{0.353} & & & & & \multicolumn{2}{|c|}{0.999} & \multicolumn{2}{|c|}{0.986} \\
\hline
\end{tabular}

Table 8. Regressions results between density and vegetation complexity of fish assemblages; NDVI - Normalized Difference Vegetation Index; EVI - Enhanced Vegetation Index.

\begin{tabular}{|c|c|c|c|c|c|c|c|c|}
\hline & \multicolumn{8}{|c|}{ Density } \\
\hline & \multicolumn{4}{|c|}{ NDVI } & \multicolumn{4}{|c|}{ EVI } \\
\hline & \multicolumn{2}{|c|}{ Abundance } & \multicolumn{2}{|c|}{ Richness } & \multicolumn{2}{|c|}{ Abundance } & \multicolumn{2}{|c|}{ Richness } \\
\hline & B & $P$ & B & $P$ & B & $p$ & B & $\mathrm{p}$ \\
\hline Point & -0.085 & 0.881 & 0.012 & 0.983 & -0.024 & 0.967 & 0.216 & 0.701 \\
\hline $90 \mathrm{~m}$ & 0.117 & 0.873 & 0.370 & 0.609 & 0.164 & 0.826 & 0.066 & 0.929 \\
\hline $150 \mathrm{~m}$ & -0.048 & 0.951 & 0.000 & 1.000 & 0.219 & 0.776 & -0.083 & 0.913 \\
\hline $210 \mathrm{~m}$ & 0.040 & 0.961 & -0.146 & 0.854 & -0.141 & 0.861 & -0.024 & 0.976 \\
\hline $270 \mathrm{~m}$ & 0.076 & 0.926 & -0.235 & 0.771 & -0.219 & 0.787 & 0.045 & 0.955 \\
\hline $330 \mathrm{~m}$ & 0.054 & 0.948 & -0.092 & 0.909 & -0.023 & 0.978 & 0.076 & 0.925 \\
\hline $390 \mathrm{~m}$ & -0.009 & 0.991 & 0.044 & 0.955 & 0.055 & 0.944 & -0.051 & 0.948 \\
\hline $450 \mathrm{~m}$ & -0.037 & 0.959 & 0.089 & 0.900 & 0.058 & 0.936 & -0.088 & 0.903 \\
\hline$r^{2}$ & \multicolumn{2}{|c|}{0.637} & \multicolumn{2}{|c|}{0.589} & \multicolumn{2}{|c|}{0.618} & \multicolumn{2}{|c|}{0.595} \\
\hline $\mathbf{P}$ & \multicolumn{2}{|c|}{0.999} & \multicolumn{2}{|c|}{0.999} & 0.9 & & \multicolumn{2}{|c|}{0.996} \\
\hline
\end{tabular}

\begin{tabular}{|c|c|c|c|c|c|c|c|}
\hline \multicolumn{8}{|c|}{ Complexity } \\
\hline \multicolumn{4}{|c|}{ NDVI } & \multicolumn{4}{|c|}{ EVI } \\
\hline \multicolumn{2}{|c|}{ Abundance } & \multicolumn{2}{|c|}{ Richness } & \multicolumn{2}{|c|}{ Abundance } & \multicolumn{2}{|c|}{ Richness } \\
\hline B & $\mathrm{P}$ & B & $\mathrm{p}$ & B & $\mathrm{p}$ & B & $\mathrm{p}$ \\
\hline-0.239 & 0.629 & 0.133 & 0.797 & -0.379 & 0.468 & -0.176 & 0.749 \\
\hline 0.154 & 0.810 & 0.034 & 0.960 & -0.103 & 0.871 & 0.180 & 0.789 \\
\hline 0.349 & 0.612 & -0.043 & 0.952 & 0.414 & 0.541 & 0.039 & 0.957 \\
\hline 0.134 & 0.851 & -0.206 & 0.783 & 0.471 & 0.356 & -0.050 & 0.926 \\
\hline-0.013 & 0.986 & -0.111 & 0.885 & -0.054 & 0.937 & -0.225 & 0.756 \\
\hline-0.052 & 0.941 & 0.083 & 0.912 & -0.045 & 0.948 & 0.087 & 0.905 \\
\hline-0.140 & 0.828 & 0.158 & 0.814 & -0.203 & 0.755 & 0.198 & 0.776 \\
\hline \multicolumn{2}{|c|}{0.370} & \multicolumn{2}{|c|}{0.505} & \multicolumn{2}{|c|}{0.312} & \multicolumn{2}{|c|}{0.493} \\
\hline \multicolumn{2}{|c|}{0.971} & \multicolumn{2}{|c|}{0.998} & \multicolumn{2}{|c|}{0.931} & \multicolumn{2}{|c|}{0.993} \\
\hline
\end{tabular}




\section{Discussion}

There is a predominance of the genus Rhagovelia in the sampled Heteroptera communities. This pattern might be explained by the gregarious habits that individuals of the genus Rhagovelia present, agreeing with other studies performed at this region with the same group (Dias-Silva et al., 2010; Nieser and Melo, 1997). For fish populations, we observed the predominance of Characiformes and Siluriformes orders. This pattern is common for non-estuarine localities (Lowe-McConnell, 1987) and was already observed in other studies performed in streams (e.g., Araújo and Tejerina-Garro, 2007; Benedito-Cecilio et al., 2004; Melo et al., 2009; Pereira et al., 2008).

Generally, streams that exhibit dominance of benthic species (e.g., Aspidoras sp.) are classified as unsuitable places (Roth et al., 1996). However, many streams of the Amazon basin exhibit natural sandy substrate, which is a characteristic related to the geological formation of the basin. Therefore, the presence or abundance of species of the genus Aspidoras are not valid indicators of degradation in the sampled streams. This was confirmed when we found that streams that had the highest abundances of Aspidoras sp. (69 from a total of 116 collected specimens) presented integrity indices equal to 0.63 , which considers that the habitat is submitted to intermediary levels of degradation.

We also observed high abundance of the omnivorous species Knodus victoriae and Moenkhausia xinguensis. These species are usually associated with integrate sites and low sedimentation (Casatti et al., 2008; Langeani, 2009; Oliveira and Bennemann, 2005). Since Knodus victoriae and Moenkhausia xinguensis are nektonic species, they need sites with relatively high water column height in order to acquire food in this portion (Langeani, 2009). This requirement causes these species to respond negatively to silted sites, reinforcing the existence of sites with no degradation or with an intermediate level of degradation.

In our study, we found no relationship between physicochemical/physical variables and descriptors of biotic assemblages. The intake of sediments prevenient from unstable soils that are next to the stream (Allan, 2004; Vondracek et al., 2005) can be considered one possible factor that influences the biota. We observed that the landscape matrix area of our study is predominantly composed of agriculture and grassland. This type of matrix is usually negatively correlated with the physical integrity and stability of the stream, which leads to the decrease of the richness and abundance of biotic groups (Pinto et al., 2006; Trimble, 1997).

Although only confirmed for Heteroptera, we conclude that the riparian coverage showed a negative effect on biota. The association found between canopy openness and Heteroptera indicates that Heteroptera is more sensitive to changes in vegetation than fish (which were not associated with canopy openness). Therefore, we conclude that, from the tested groups, only Heteroptera responds well to changes in landscape. This indicates that this group is a good indicator of preservation of vegetation coverage.

We observed that physical and physicochemical variables of the water did not show any effect on the Heteroptera community of this study, demonstrating either that the variation in these variables is not intense or that the group exhibits great plasticity to physicochemical variations. Thus, the group is affected only by environmental variables, such as shading, as described by Dias-Silva et al. (2010), in a study conducted in streams of eastern Mato Grosso.

Additionally, aquatic Heteroptera are recognized for being resistant to natural disturbances, such as flood pulses, inorganic sediment delivery to streams and changes 
in physical and physicochemical characteristics of the water (Gordon et al., 1992). This feature may imply that these communities are less effective bioindicators of water quality. However, changes of magnitude and frequency of occurrence of these disorders might be negatively correlated with the biota (Buss et al., 2003; Ferreira et al., 2006; Magner et al., 2004; Simon and Rinaldi, 2000). In this way, we can expect that Heteroptera is more sensitive to anthropogenic disturbances than fish.

The sensitivity of the Heteroptera fauna can also be justified by its the positive relationship with $\mathrm{HIH}$ and by the no relationship of this index with the icthyofauna. This index is easy to apply and summarizes a series of questions about the use of areas adjacent to the channel, the format and channel stability on availability, habitat complexity and others hydrological factors (even though these indices are measured visually).

The non-relation between fish fauna and metrics performed in the sites might still be a problem caused by the lack of reference streams. When we aim to relate biota to environmental disturbances, the choice of reference streams (i.e., sites that have stable and pristine characteristics of the channel; Harrelson et al., 1994) is of great importance (Barbour et al., 1999; Harrelson et al., 1994; Hughes, 1995). This argument reinforces the sensitivity feature of Heteroptera that, even without reference sites, was able to capture the variation in canopy openness and HIH through richness and abundance of genera.

Relationships between fish species and human disturbance are recurrent in literature (e.g., Casatti, 2005; Casatti et al., 2008; Langeani, 2009). Casatti et al. (2005) found that fish dependent on rocky substrates are more affected by habitat loss and deterioration. Additionally, richness and abundance of native species tend to be higher in reference sites than in impacted sites (Casatti et al., 2008b; Ferreira et al., 2006).

At last, we conclude that the fauna of Heteroptera is more sensitive to human impacts than icthyofauna. This sensitivity is demonstrated by the negative relationship of Heteroptera with the canopy openness over the stream and positively related to the integrity of the environment. These relationships were not found for the icthyofauna. This also characterizes Heteroptera as a good indicator of impacts on riparian vegetation. However, for monitoring purposes, we cannot simply discard fish as potential bioindicators, because the icthyofauna might be related to other variables associated to other human impacts (e.g., type of channel substrate or margin stability).

Acknowledgements. We thank CNPq for the doctorate scholarship granted to Karina Dias da Silva, CAPES for the doctorate scholarship granted to Thiago Viera Bernardi, FAPEG for the doctorate scholarship granted to Eduardo dos Santos Pacífico ( $n^{\circ}$ 201300377430172), Instituto de Pesquisa Ambiental da Amazônia (Ipam) for logistical and financial support, the National Science Foundation (NSF - DEB0949996) for funding this research, Dr. Rogério Pereira Bastos for providing required physical space to identify the collected fish and Nelson Silva Pinto for giving a sexy title to this work.

\section{REFERENCE}

[1] Allan, J.D. (2004): Landscapes and riverscapes: The influence of land use on stream ecosystems. -Annual Review of Ecology Evolution and Systematics 35: 257-284.

[2] Araújo, N.B., Tejerina-Garro, F.L. (2007): Composição e diversidade da ictiofauna em riachos do Cerrado, bacia do ribeirão Ouvidor, alto rio Paraná, Goiás, Brasil. - Revista Brasileira de Zoologia 24: 981-990. 
[3] Barbour, M.T., Gerritsen, J., Snyder, B.D., Stribling, J.B. (1999): Rapid Bioassessment Protocols for Use in Streams and Wadeable Rivers: Periphyton, Benthic Macroinvertebrates and Fish. - Environmental Protection.

[4] Benedito-Cecilio, E., Minte-Vera, C. V, Zawadzki, C.H., Pavanelli, C.S., Rodrigues, F.H.G., Gimenes, M.F. (2004): Ichthyofauna from the Emas National Park region: composition and structure. - Brazilian Journal of Biology 64: 371-82.

[5] Buckup, P.A. (1993): The monophyly of the Characidiinae, a Neotropical group of characiform fishes (Teleostei: Ostariophysi). - Zoological Journal of the Linnean Society 108: 225-245.

[6] Buss, D.F.D.F., Baptista, D.F.D.F., Nessimian, J.L.J.L. (2003): Conceptual basis for the application of biomonitoring on river water quality evaluation programs. - Cadernos de saúde pública Ministério da Saúde Fundação Oswaldo Cruz Escola Nacional de Saúde Pública 19: 465-473.

[7] Buss, L.W. (1986): Competition and community organization on hard surfaces in the sea, in: Diamond, J., Case, T.J.C.P. (Eds.), Community Ecology. - Harper and How.

[8] Cabette, Helena S R, Giehl, N.F.S., Dias-Silva, K., Juen, Leandro, Batista, J.D. (2010): Distribuição de Nepomorpha e Gerromorpha (Insecta: Heteroptera) da bacia do rio SuiáMiçú, MT: Riqueza relacionadas à qualidade de água e de hábitat, in: dos Santos, J.E., Galbiati, C., Moschini, L.C.E. (Eds.), Gestão e Educação Ambiental. - Água, Biodiversidade e Cultura. RiMa, São Paulo.

[9] Callisto, M. (2001): Macroinvertebrados Bentônicos como Ferramenta para Avaliar a Saúde de Riachos. - Revista Brasileira de Recursos Hídricos 6: 71-82.

[10] Callisto, M., Goulart, M., Barbosa, F.A.R., Rocha, O. (2005): Biodiversity assessment of benthic macroinvertebrates along a reservoir cascade in the lower São Francisco river (northeastern Brazil). - Brazilian Journal of Biology 65: 229-40.

[11] Callisto, M., Moreno, P., Barbosa, F.A.(2001): Habitat diversity and benthic functional trophic groups at Serra do Cipó, Southeast Brazil. - Brazilian Journal of Biology 61: 25966.

[12] Casatti, L. (2005). Fish assemblage structure in a first order stream, southeastern Brazil: longitudinal distribution, seasonality, and microhabitat diversity. - Biota Neotropica 5: 19.

[13] Casatti, L., Ferreira, C.P., Langeani, F. (2008a): A fish-based biotic integrity index for assessment of lowland streams in southeastern Brazil. - Hydrobiologia 623: 173-189.

[14] Casatti, L., Ferreira, C.P., Langeani, F. (2008b): A fish-based biotic integrity index for assessment of lowland streams in southeastern Brazil. - Hydrobiologia 623, 173-189.

[15] Colwell, R.K. (2004): EstimateS: Statistical estimation of species richness and shared species from samples. (Software and User's Guide). Freeware for Windows and Mac OS.

[16] De Marco, P.J., Latini, A.O., Resende, D.C. (2005): Thermoregulatory constraints on behavior: patterns in a Neotropical dragonfly assemblage. - Neotropical Entomology 34:155-162.

[17] Dias-Silva, K., Cabette, H S R, Juen, L, De Marco, P. (2010). The influence of habitat integrity and physical-chemical water variables on the structure of aquatic and semiaquatic Heteroptera. - Zoologia 27: 918-930.

[18] Ferreira, C.D.P., Casatti, L., Paulo, S. (2006): Influência da estrutura do habitat sobre a ictiofauna de um riacho em uma micro-bacia de pastagem, São Paulo, Brasil. - Revista Brasileira de Zoologia 23: 642-651.

[19] Gordon, N.D., McMahon, T.A., Finlayson, B.L. (1992). Stream Hydrology: An Introduction for Ecologists, Biologia Ambientale. - John Wiley and Sons.

[20] Greenwood, H., O'Dowd, D J, Lake, P.S. (2004): Willow (Salix x rubens) invasion of the riparian zone in south-eastern Australia: reduced abundance and altered composition of terrestrial arthropods. - Diversity and Distributions 10: 485-492. 
[21] Harrelson, C.., Rawlins, C.., Potyondy, J. (1994): Stream Channel Reference Sites : An Illustrated Guide to Field Technique. Department of Agriculture, Forest Service, Rocky Mountain Forest and Range Experiment Station, Fort Collins, Colorado.

[22] Heltshe, J.F., Forrester, N.E. (1983): Estimating species richness using the jackknife procedure. - Biometrics 39: 1-11.

[23] Holland-Clift, S., O’Dowd, Dennis J, Mac Nally, R. (2011): Impacts of an invasive willow (Salix $\times$ Rubens) on riparian bird assemblages in south-eastern - Australia. Austral Ecology 36: 511-520.

[24] Huete, A.R., Liu, H.Q., Batchily, K., Van Leeuwen, W. (1997): A comparison of vegetation indices over a global set of TM images for EOS-MODIS. - Remote Sensing of Environment 59, 440-451.

[25] Hughes, R.M. (1995): Defining acceptable biological status by comparing with reference conditions., in: Davis, W.S., Simon, T.P. (Eds.), Biological Assessment and Criteria: Tools for Water Resource Planning and Decision Making. CRC Press, Florida2.

[26] Karr, J. (1993). Measuring biological integrity: lessons from streams, in: Woodley, S., Kay, J., Francis, G. (Eds.), Ecological Integrity and the Management of Ecosystems. - St. Lucie Press..

[27] Langeani, F. (2009): A fish-based biotic integrity index for assessment of lowland streams in southeastern Brazil. - Hydrobiologia 623:173-189.

[28] Lowe-McConnell, R.H. (1987) Ecological studies in tropical fish communities, Science. Cambridge University Press.

[29] Magner, J.A., Payne, G.A., Steffen, L.J. (2004) Drainage effects on stream nitrate-N and hydrology in south-central Minnesota (USA). - Environmental Monitoring and Assessment 91: 183-198.

[30] Melo, T.L. De, Tejerina-Garro, F.L., Melo, C.E. De. (2009): Influence of environmental parameters on fish assemblage of a neotropical river with a flood pulse regime, Central Brazil. - Neotropical Ichthyology 7: 421-428.

[31] Minshall, G.W., Petersen, R.C., Cummins, K.W., Bott, T.L., Sedell, J.R., Cushing, C.E., Vannote, R.L. (1983): Interbiome comparison of stream ecosystem dynamics. Ecological Monographs 53: 1-25.

[32] Montgomery, D.R. (1999): Process domains and the river continuum. - Journal of the American Water Resources Association 35:397-410.

[33] Murray, S., Innes, J.L. (2009). Effects of environment on fish species distributions in the Mackenzie River drainage basin of northeastern British Columbia, Canada. - Ecology of Freshwater Fish 18: 183-196.

[34] Nieser, M., Melo, A.L. (1997): Os Heterópteros Aquáticos de Minas Gerais. UFMG, Belo Horizonte, MG, Belo Horizonte.

[35] Oertli, B. (2008): The use of dragonflies in the assessment and monitoring of aquatic habitats. - In: Cordoba-Aguilar, A. (Ed.) Model Organisms for Ecological and Evolutionary Research, Oxford University Press, Oxford.

[36] Oliveira, D.C., Bennemann, S.T. (2005): Ictiofauna, recursos alimentares e relações com as interferências antrópicas em um riacho urbano no sul. - Biologia 5: 95-107.

[37] Pereira, A.F., Oliveira, L.G., Tejerina-Garro, F.L., Mérona, B. (2008): Fish-habitat relationship in a tropical river under anthropogenic influences. - Hydrobiologia 598:315324.

[38] Pereira, D.L. V, Melo, A.L. (2007): Aquatic and semiaquatic Heteroptera (Insecta) from. - Acta Amazonica 37: 643-648.

[39] Pinto, B.C.T., Araujo, F.G., Hughes, R.M. (2006): Effects of Landscape and Riparian Condition on a Fish Index of Biotic Integrity in a Large Southeastern Brazil River. Hydrobiologia $556: 69-83$.

[40] Resh, V.H., Norris, R.H., Barbour, Michael T. (1995) : Design and implementation of rapid assessment approaches for water resource monitoring using benthic macroinvertebrates. - Australian Journal of Ecology 20: 108-121. 
[41] Richter, M. (2003): Gross fluxes of nitrogen in grassland soil exposed to elevated atmospheric pCO2 for seven years. - Soil Biology and Biochemistry 35: 1325-1335.

[42] Rosenberg, D.M., Resh, V.H. (1993): Introduction to freshwater biomonitoring and benthic macroinvertebrates. - In: Rosenberg, D.M., Resh, V H (Eds.), Freshwater Biomonitoring and Benthic Macroinvertebrates, Chapman and Hall.

[43] Roth, N.E., Allan, J.D., Erickson, D.L. (1996): Landscape influences on stream biotic integrity assessed at multiple spatial scales. - Landscape Ecology 11: 141-156.

[44] Rouse, J.W., Haas, R.H., Schell, J.A., Deering, D.W. (1974): Monitoring vegetation systems in the Great Plains with ERTS, in: Freden, S.C., Becker, M.A. (Eds.), Third ERTS Symposium. NASA SP-351.

[45] Simon, A., Rinaldi, M. (2000): Channel instability in the loess area of the midwestern United States. - JAWRA Journal of the American Water Resources Association 36: 133150 .

[46] Trimble, S.W. (1997). Stream channel erosion and change resulting from riparian forests. - Geology 25: 467-469.

[47] Vannote, Robin L, Minshall, G Wayne, Cummins, Kenneth W, Sedell, James R, Cushing, Colbert E. (1980): The River Continuum Concept. - Canadian Journal of Fisheries and Aquatic Sciences 37: 130-137.

[48] Vari, R.P. (1989): Systematics of the Neotropical Characiform Genus Curimata Bosc (Pisces: Characiformes). - Smithsonian Contributions to Zoology 378: 1-63.

[49] Vari, R.P. (1991): Systematics of the Neotropical Characiform Genus Steindachnerina Fowler ( Pisces : Ostariophysi ). - Smithsonian Contributions to Zoology 507: 1-118.

[50] Vari, R.P., Williams, A.M. (1987): Headstanders of the neotropical anostomid genus Abramites ( Pisces: Characiformes: Anostomidae ). - Proceedings of the Biological Society of Washington 100: 89-103.

[51] Vondracek, B., Blann, K.L., Cox, C.B., Nerbonne, J.F., Mumford, K.G., Nerbonne, B. a, Sovell, L. a, Zimmerman, J.K.H. (2005). Land use, spatial scale, and stream systems: lessons from an agricultural region. - Environmental management 36: 775-91.

[52] Warren, D.R., Mineau, M.M., Ward, E.J., Kraft, C.E. (2010): Relating fish biomass to habitat and chemistry in headwater streams of the northeastern United States. Environmental Biology of Fishes 88: 51-62. 